\title{
Arrhenatherum elatius (L.) Beauv. - a review, and evaluation of tall oat grass for dryland and hawkweed-affected country in the South Island
}

\author{
B.J. WILLS and J.S.C. BEGG \\ Landcare Research, PO Box 276, Alexandra
}

\section{Abstract}

Tall oat grass has a long history in New Zealand agriculture. Reference was made to it in the $1880 \mathrm{~s}$ as a useful grass and it was included in many trials such as those of Macpherson, Cockayne, Calder, Dunbar, Sievwright, Moore and others. While the survival and performance of tall oat grass was generally reported as being good, observations on palatability were mixed. The growth pattern was typically noted as being one of early spring growth, rapidly changing to reproductive form thereafter with a consequent decrease in acceptability to stock. In 1988, new accessions of tall oat grass originating from diverse countries were introduced to New Zealand from the US Department of Agriculture. This paper describes the physical characteristics of tall oat grass and field performance at Galloway Station, a site badly affected by hawkweed, and on other farms. This grass appears best suited to moderate-low rainfall areas $(400-700 \mathrm{~mm}$ p.a.) which are not too exposed or too cold and it shows good potential for survival and spread in the drier soil conditions which result from hawkweed invasion in mid-altitude grassland areas. Two accessions, one from Chile and the other from Switzerland, have been identified which have superior wैmter performance, rust resistance and are less prone to bolting into a reproductive phase in the spring. These, along with a preliminary selection containing a wider genetic base, are being commercially evaluated at present.

Keywords: Arrhenatherum elatius, tall oat grass, hawkweeds, plant selection, vegetation sustention

\section{Introduction}

Tall oat grass (Arrhenatherum elatius (L.) Beauv.) is considered to be an important pasture grass for New Zealand, particularly for application in drought-prone and some hawkweed (Hieracium spp.)-affected areas. This paper reviews historical use of the plant in New Zealand and recent overseas literature, it provides information from several farmers on current utilisation of tall oat grass in the South Island, and it presents data on evaluation of tall oat grass introductions for commercial development in $\mathrm{NZ}$
Literature review

Tall oat grass is a native of Europe, occurring from $70^{\circ} \mathrm{N}$. in Norway to the Atlas Mountains in North Africa, and is very common in the UK. The Caucasus form its eastern limit and, while most frequent below $300 \mathrm{~m}$ altitude, it can be found to $1300 \mathrm{~m}$ in the south of its range. In a review of the plant, Pfitzenmeyer (1962) gave the following description: "Sites sheltered from strong winds and very low temperatures, particularly sunny aspects, are the preferred habitat. Favourable edaphic factors include soils, particularly calcareous types, of moderate to high fertility and a $\mathrm{pH}$ range of 5.0-8.0, the optimum being 6.0-7.5".

Tall oat grass is described as being moderately tolerant of grazing and, in non-bulbous ecotypes, winter activity is frequently evident. Drought tolerance is shown by its presence in summer-dry regions (Mediterranean), it is deep rooted and may produce short rhizomes. Genetically the plant is tetraploid $[2 n(4 x)=28]$ and is wind pollinated although self-fertilisation may occur. Seed does not require an extended dormancy period - it can germinate immediately after ripening - and germination is typically about $70 \%$.

In New Zealand, tall oat grass was recommended for pasture use in the late 1800s (MacKay 1887) and was_included-in-several-early-experimental ${ }^{-}$triāis $^{-}$ (Earnshaw 1910) and 'regrassing' experiments (MacPherson 19 10). By 1912, tall oat grass was recorded as performing well in all but the spring 1910 sowing at Eamscleugh, was making "fair growth" at Sawdon (MacPherson 1912) and excellent growth at Lindis Crossing (MacPherson 1913).

In 1920, Dr L. Cockayne revisited the Eamscleugh site and conducted palatability experiments on the various plants there, this in late February. Tall oat grass, which apparently occupied a good proportion of the vegetation-in the cultivated enclosure (\&out 8 ha), was only lightly grazed during this exercise. However, the grazing followed a prolonged drought and a very hot summer (Cockayne 1920).

Cockayne progressed with his regrassing experiments on Northburn Station in Central Otago (Cockayne $1922 \mathrm{a}, \mathrm{b}, \mathrm{c})$ utilising a wide range of plant species including tall oat grass. Douglas (1970) reviewed the history of Cockayne's experiments and commented on the present state of them. By 1935 the majority of the plots were dominated by tall oat grass (described as 
unpalatable by $\mathrm{Dr}$ H.H. Allen). This situation remained largely unchanged by the 1970s when Douglas reported that tall oat grass had spread at least a quarter of a mile $(0.4 \mathrm{~km})$ from some plots and was largely ungrazed. A detailed assessment of the vegetation in the Cockayne trials was completed in 1985 (Wills \& Begg 1986). Tall oat grass still dominated the shady aspect enclosures and had spread considerable distances $(1-2 \mathrm{~km})$ outside some.

In a review of New Zealand grassland plants, Levy (1925) identified the following characteristics for tall oat grass: it grew best under "moderate-low" to "moderate-high" soil fertility conditions; was tolerant of a soil moisture content from "fairly dry" to "wet"; had a tendency to colonise more "shady" aspects; maximum growth occurred in spring with moderate growth in early spring and summer; highly palatable as hay, less so as herbage. Hilgendorf (1940) concluded it was very drought hardy, but also unpalatable unless mixed as hay. In a report on the regrassing trials at Pisa Flat (Central Otago), Calder (1944) listed lucerne and tall oat grass as having given the best results and commented that the latter was readily eaten by sheep, despite the undesirability noted in some other districts.

In 1974 Douglas reviewed several of the more important earlier grass species introductions into the South Island tussock grasslands. Along with cocksfoot, tall oat grass was frequently referred to as one of the more successful plants in these, although its palatability was questioned in some reports. Moore (1976), commenting on the Molesworth trials, indicated the successful establishment of tall oat grass and its moderate palatability'and provision of feed at certain times of the year, particularly winter. Of note was its dominance in some tussock areas by the late 1950s, and its persistence under very unfavourable circumstances. Lunn (1951) also referred to "suppression, but not replacement, of other species by tall oat grass on shady faces" in an article on Northburn and other Central Otago trials. Tall oat grass was discussed in Scott et al. (1985); it was considered to have possibilities as a drought tolerant grass and for provision of standing winter herbage, particularly in the moderately fertile, low rainfall zone.

In the USA, Plummer et al. (1968) recommended tall oat grass as a rangeland restoration plant in Utah. Vassileva (1987) considered it a more efficient plant for hill country soil protection and moisture conservation than cocksfoot and several legume species in Bulgaria. Following its introduction into the USA in the early 1700s (and latterly to Australia and New Zealand), Hafenrichter et al. (1968) described it as a useful, shade-tolerant, drought-hardy conservation plant adapted to low-fertility soils. They also commented on its compatibility with legumes and its high palatability, the latter adversely effecting its persistence unless the plant was carefully managed. Wheeler (1950) recommended that the plant may be used for pasture or meadow, that it can give good hay yields and is considered to be a good companion plant for sweet clover and other legumes in short rotation.

Seed harvest difficulties commonly occur (Voight \& MacLauchlan 1985) due to the unevenness with which seed ripens and the ease with which it shatters prior to maturation. In the USA a cultivar developed in Oregon, Tualatin, has been selected for improved seed retention. Seed yields are normally in the range 220-450 kg/ha; there are approximately 330000 seeds per $\mathrm{kg}$ and normal sowing rates (cropping) are $30-45 \mathrm{~kg} / \mathrm{ha}$.

\section{Tall oat grass use in the South Island}

The practical application and utilisation of tall oat grass has been investigated on several properties in Central Otago and the Mackenzie Basin. These include Lagoon Valley (R. Kane), Black Forest (P. Innes), Northburn (K. Lake), Belfield (J. McKenzie) and Tara Hills (AgResearch).

On Lagoon Valley, Hawea, tall oat grass had spread from early plant introduction trials and now covers some 200 ha of the property. With fertiliser applications and a consequent lift in fertility over the past 10 years, tall oat grass has become much more apparent. During spring it generally bolts to seed and is considered to be unpalatable to stock (Merino and halfbreed) at that time. However, lambing' ewes are kept on it mid-late September. Tall oat grass is considered to provide best grazing in autumn, and sheep generally do well on it at that time. The comment was made by the runholder that soil structure appears to be considerably improved under established stands of tall oat grass. The plant seems to be quite competitive, but this is more than offset by its ability to grow well under stressful conditions.

At nearby Northburn Station, tall oat grass has proliferated from Cockayne's revegetation trials which were established in the early 1900s. Under the semiarid conditions experienced there, it has preferentially populated shaded faces and only a light covering occurs on sunny slopes. While providing good ground cover, tall oat grass was not considered to be particularly palatable, although blocks containing it were valuable for grazing during autumn. Lunn's (1951) comments on the suppression of other plant species by tall oat grass remain valid at Northburn wherever dense stands of the grass occur.

At Black Forest, tall oat grass is considered to provide good ground cover over some 3000 ha of the run. Most importantly, the soil flora and fauna has reportedly improved and the microclimate has been 
restored in areas which were severely depleted. The origin of the plant dates back to McGillivray's early trial work and, in this case, its spread was actively encouraged by hand harvesting and aerial spreading during the 1950s and 1960s. Tall oat grass is dominant on the dark faces but hawkweed is still invading on these. The runholder considers that the grass may have difficulty holding its own against this invasion in the long-term, but it is a far more durable grass than anything else currently available. Its ability to resist grass grub predation is a particularly valuable attribute.

Tall oat grass provides good late-season production on sunny faces at Black Forest if spelled early on. The entire lamb flock (some 2000 Merino lambs) is weaned in February onto 160 ha of tall oat grass mixed with lotus and alsike clover. While it is considered to be an important source of early spring feed at Black Forest, it is also important for overwintering stock on their lower country. Palatability is good with the predominantly Merino flock and is considered to be better than most cocksfoots, especially later in the growing season. The plant establishes best on rocky/shale covered areas, with poor establishment on hawkweed-dominant land unless the ground is tilled or disturbed by mechanical means. Reseeding is prolific, but the current scarcity of commercial seed sources is a problem.

Trials with tall oat grass and other species were established at Belfield, Hakataramea Valley, in January 1990 using a till seeder. Approximately 2 ha of tall oat grass was sown at $6 \mathrm{~kg} / \mathrm{ha}$ into an agricultural situation (Woodman \& Fraser 1991). The most suitable management technique was found 'to be rotational grazing. The duration of this under normal conditions -is-7-10 days -on, 3 -weeks off, al though this past (higher rainfall) season the period on has been increased to 14 days. Under such a grazing system, early flowering is not considered to be a problem. Conversely, set stocking/ spelling has a tendency to allow tall oat grass to become rank. Survival has been good, with the tall oat grass sward gradually thickening up. Seedling spread is noticeable even on better soils and performance is considered to be on a par with cocksfoot. In contrast with the situation in open grassland, no tendency for tall oat grass to compete with and dominate other pasture plants has been noted to date. During autumn, the palatability of tall oat grass appears to be better than that of cocksfoot.

At Tara Hills, tall oat grass has been the outstanding grass in hawkweed-affected Acheron soils on the "red flats" near Omarama (B. Allan, pers. comm.). Under such circumstances, a hardy legume such as Caucasian or red clover, or birdsfoot trefoil, is considered necessary to assist the continued performance of the grass. Of major concern in hawkweed-affected tussock grasslands, particularly in drought-prone areas, is the ability of soils to accept and retain moisture. Despite some immediate problems with seed harvest and sowing, tall oat grass does have a record for good drought-hardiness and an ability to spread vigorously during favourable seasons, and thus can assist with the sustention of vegetation cover under harsh conditions. Acceptable performance on sites where the plant has spread from old trials, as reported above, provided justification for a recent selection programme based on material introduced from the USDA.

\section{Methods}

Tall oat grass was evaluated on light, stony Molyneux soils at Earnscleugh Research nursery, and on hawkweed affected, Blackstone Hill BGE soils at Galloway Station. In 1988,131 accessions of tall oat grass were introduced from the US Dept. of Agriculture. This germplasm originated from diverse countries - Turkey, Switzerland, Spain, Portugal, Iraq, Yugoslavia, Bulgaria, Germany, Poland, Australia, USSR and USA to name a few. To these were added naturalised accessions obtained from 3 South Island sites - Bendigo, Northburn and Black Forest. A full listing of the collection, including PI numbers, is available from the authors.

This material was grown on from seed or tillers and introduced into a nursery-based selection trial consisting of 134 accessions $\mathrm{x} 4$ replicates $\mathrm{x} .3$ plants per replicate (a total of some 1600 plants).-Selection criteria aimed at improving seasonal spread of vegetative growth and especially winter hardiness, later flowering and seed set, and production of rhizomes to enhance vegetative spread. Measurements included seasonal vegetative growth, tiller production and angle, flowering time and floral frequency, rhizome production and plant vigour.

In 1990, elite selections from the earlier trial were transplanted to Galloway Station for field evaluation and in 1992 to another nursery site foi more detailed observation and seed bulking. In view of a need to accelerate evaluation and release of improved tall oat grass germplasm, the discussion below concentrates on the latter trials.

\section{Results and discussion}

\section{Tall oat grass selection}

Growth and performance has shown considerable variation, both within those plants established in 1988, in the elite isolates (derived from 38 of the original 134 accessions) transplanted to a second nursery site in 1992, and in those transplanted to Galloway Station beginning 1990. 
A preliminary selection based on performance selection from the original 1988 plantings has been released for commercial evaluation and is currently being grown on for seed. The origins of the accessions included in this release are as follows:

$\begin{array}{llllll}\text { PN } & 3367 & \text { (Switzerland) } & \text { PN } & 3372 & \text { (Switzerland) } \\ \text { PN } & 3376 & \text { (Netherlands) } & \text { PN } & 3379 & \text { (Greece) } \\ \text { PN } & 3392 & \text { (Yugoslavia) } & \text { PN } & 3398 & \text { (Poland) } \\ \text { PN } & 3408 & \text { (Yugoslavia) } & \text { PN } & 3413 & \text { (Australia) } \\ \text { PN } 3442 \text { (USSR) } & \text { PN } & 3445 & \text { (Spain) } \\ \text { PN } 3452 & \text { (USA) } & \text { PN } & 3458 & \text { (USA) } \\ \text { PN } 3468 \text { (USSR) } & \text { PN } & 3470 & \text { (USSR) }\end{array}$

Performance has been good despite a wet growing season and approximately $9 \mathrm{~kg}$ of seed has now been harvested (A. Stewart pers. comm.) which will serve as a base for a larger seed-increase area for 1994/95.

In terms of vigour, growth and winter performance, 2 elite lines (PN 3344 ex Chile and PN 3365 ex Switzerland) transplanted in 1992 have ranked consistently higher than all others. Figure 1 indicates the relative performance of the top 10 elite lines during recent assessments.

The Chilean line has proved to be very cold tolerant; it grows moderately well during spring, and is rust resistant and later flowering. It is moderately tine-leaved with erect foliage (cf. lax foliage in the locally naturalised Northburn material), the Swiss line being fine-leaved. It shows good ability to spread, as shown below in both the basal growth and in the higher number of stems recorded at Galloway last spring (Figure 2).
Grazing trials were carried out on the 1988 planting block with satisfactory results. Further grazing trials are planned for the elite 1992 plantings this winter and spring.

In 1990, 15 accessions of tall oat grass were selected from parent plants in the nursery, based on their performance under grazing and for regrowth and apparent rhizomatous spread. Two replicates of 5 plants each were transplanted into a hawkweed sward at Galloway. No fertiliser was applied. These plants were assessed annually for growth parameters and especially production of tillers (Figure 3). Plant vigour peaked in 1993 when all accessions recorded vigour rankings between $2.6 \& 3.5$ (from a range of 1 [dead] - 5). Since then, plant vigour has decreased markedly (to between 1.2 and 2.5 for 1994). Despite this, one accession performed well with regard to its ability to spread via tillers - PN 3344 which originated from Chile.

The performance of the Chilean accession was closely followed by that of the naturalised one from Northburn Stn, and those from the Netherlands (PN 3376) and from Australia (PN3414). Then came a larger group of accessions with little or no rhizomatous activity. Overall, performance of tall oat grass at this altitude (790 m) in Central Otago has been disappoianting, however conditions are extremely harsh and the site is very exposed. This compares to the Mackenzie Basin where the plant grows well on hill slopes to around 900 $\mathrm{m}$ asl. The performance of the Chilean accession at Galloway is consistent with its good winter performance at Eamscleugh but it is considered that intermediate altitude $(200-500 \mathrm{~m})$ hill slopes would be better suited to tall oat grass in Central Otago.

Figure 1 Phenological performance of tall oat grass accessions at Eamscleugh, 1993/94.

\begin{tabular}{|c|c|c|c|c|c|c|}
\hline & $\begin{array}{l}\text { Ranking } \\
1 \text { = Good } \\
3 \text { = Poor }\end{array}$ & $\begin{array}{l}\text { Cold Tolerance } \\
\text { Mean Ranklne } \\
\text { May } 1994\end{array}$ & $\begin{array}{c}\text { Earty Spring } \\
\text { Growth } \\
\text { Mean Ranking } \\
\text { Aug 1993 }\end{array}$ & $\begin{array}{c}\text { Earty Spring } \\
\text { Growth } \\
\text { Moan Renking } \\
\text { Sep 1993 } \\
\end{array}$ & \begin{tabular}{|c|} 
Rust \\
Resistance \\
Mean Renking \\
Sep 1993 \\
\end{tabular} & $\begin{array}{l}\text { Late Flowering } \\
\text { Mean Ranking } \\
\text { Oct/Nov 1993 }\end{array}$ \\
\hline & locession \# & & & & & \\
\hline 60 & Morthbum (NZ) & 3 & 2 & 3 & $\mathbf{3}$ & 1 \\
\hline 3344 & Chille & 1 & 2 & 2 & 1 & 1 \\
\hline 5350 & Spain & 2 & 3 & 2 & 3 & 2 \\
\hline 3355 & Spain & 3 & 2 & 2 & 3 & 3 \\
\hline 3365 & Switzertand & 1 & 2 & 2 & 2 & 1 \\
\hline 3383 & Yugoslavia & 3 & 2 & 2 & 3 & 2 \\
\hline 3398 & Poland & 2 & 1 & 1 & 2 & 2 \\
\hline 3421 & Spain & 2 & 2 & 2 & 3 & 3 \\
\hline 3458 & USA & 2 & $\mathbf{1}$ & 2 & 3 & 2 \\
\hline 3468 & USSR & 3 & 1 & 1 & 3 & 2 \\
\hline
\end{tabular}


Figure2 Morphological attributes of elite tall oat grass selections, November 1993.

\begin{tabular}{|c|c|c|c|c|c|c|c|c|}
\hline & & $\begin{array}{l}\text { Mean Plant } \\
\text { Follage Hedght } \\
\text { (cm) }\end{array}$ & $\begin{array}{l}\text { Mean Plant } \\
\text { Basal Spread } \\
\text { (cm) }\end{array}$ & $\begin{array}{l}\text { Mean leaf } \\
\text { Binde Width } \\
\text { (an) }\end{array}$ & $\begin{array}{l}\text { Mean Stem } \\
\text { Angle From } \\
\left.\text { Vertical ( }{ }^{\circ}\right)\end{array}$ & $\begin{array}{c}\text { Man } \\
\text { Flowering } \\
\text { Stem Number }\end{array}$ & $\begin{array}{l}\text { Fottage } \\
\text { Composition } \\
1=\text { lexty } \\
5 \text { =estaily }\end{array}$ & $\begin{array}{c}\text { Rust } \\
0=\text { no rust } \\
5=\text { severe rust }\end{array}$ \\
\hline \multicolumn{9}{|c|}{ Accestion : } \\
\hline 60 & Northburn (NI) & 37 & 56.5 & 5.9 & 27 & 36.5 & 2.2 & 3.8 \\
\hline 3344 & Chille & 27.5 & 60.5 & 4.95 & 30 & 86 & 3.5 & 3.3 \\
\hline 3350 & Spatin & 24 & 47 & 5.2 & 21 & 58 & 3 & 4 \\
\hline 3355 & Soain & 25.6 & 54 & 5.1 & 36 & 72 & $\mathbf{3}$ & 4 \\
\hline 3365 & Swltzerland & 23 & 57 & 4.65 & 30.5 & 79 & 2.6 & 3.3 \\
\hline 3383 & Yugoulata & 36 & 39 & 4.7 & 25 & 6.4 & 2 & 2.4 \\
\hline 3390 & Poland & 38 & 60 & 5.05 & 25 & 33.5 & 2.7 & 1.9 \\
\hline 3421 & Span & 23 & 57 & 4.4 & 25 & 56 & 3 & 4 \\
\hline 3458 & USA & 23 & 47.5 & 4.95 & 22.5 & 54.5 & 4 & 3.5 \\
\hline 3460 & uss: & 29 & 54.5 & 5.05 & 22.5 & 52.5 & 3.3 & 2.7 \\
\hline
\end{tabular}

Figure 3 Tall oat grass tillering activity.

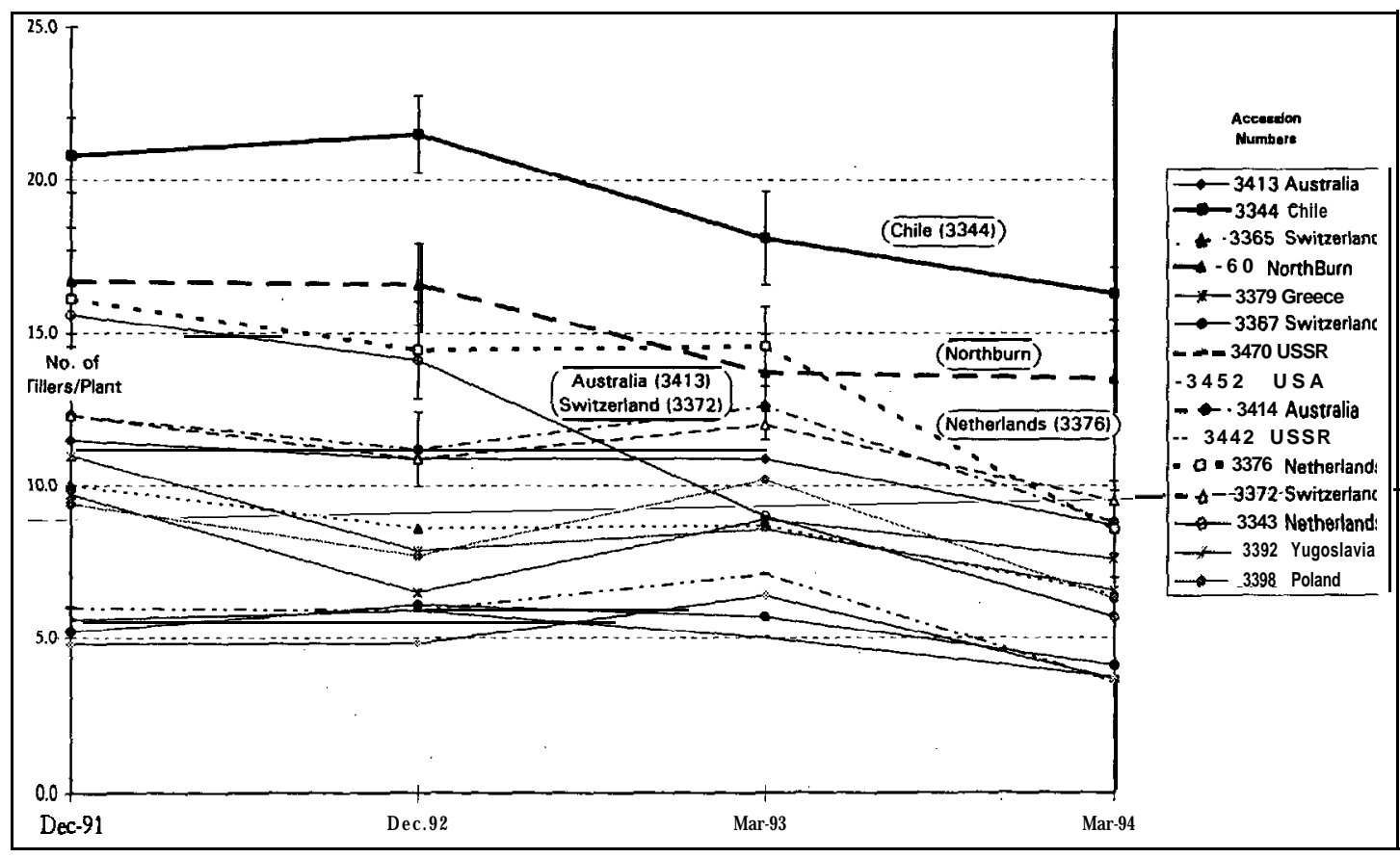

\section{Conclusion}

Tall oat grass has considerable potential for improving the sustainability of agriculture and providing good, utilisable ground cover in many areas of the South Island hill and high country. It appears best suited to moderate-low rainfall areas $(400-700 \mathrm{~mm}$ p.a.) which are not too exposed or too cold. Although current selections are struggling at an altitude of $790 \mathrm{~m}$ asl in Central Otago, the plant is performing satisfactorily at similar altitudes in the Mackenzie Basin and at lower altitudes in Otago. Tall oat grass has the potential to better survive and spread in the drier soil conditions which result from hawkweed invasion in mid-altitude grassland areas.

Two accessions, one from Chile and the other from Switzerland, have been identified which have superior winter performance, rust resistance and are less prone to bolting into a reproductive phase in the spring. These, along with a preliminary selection containing a wider 
genetic base, are being commercially evaluated at present.

\section{REFERENCES}

Berendse, F.; Elberse, W.; Geerts, R. 1992. Competition and nitrogen loss from plants in grassland ecosystems. Ecology 73 (1): 46-53.

Calder, G.G. 1944. Regrassing depleted areas in Central Otago. NZ journal of agriculture 68: 185-192.

Cockayne, L. 1920. An economic investigation of the montane tussock-grassland of New Zealand. NZ journal of agriculture 21: 177-188 (VIII), 324334 (IX).

Cockayne, L. 1922a. An economic investigation of the montane tussock-grassland of New Zealand. XII. The regrassing experiments in Central Otago. NZ journal of agriculture 24/6: 321-334 (Part I).

Cockayne, L. 1922b. An economic investigation of the montane tussock-grassland of New Zealand. XII. The regrassing experiments in Central Otago. NZ journal of agriculture 25/1: 1- 11 (Part II).

Cockayne, L. 1922c. An economic investigation of the montane tussock-grassland of New Zealand. XII. The regrassing experiments in Central Otago. NZ journal of agriculture 25/3; 129-144 (Part III).

Douglas, J.A. 1970. The Cockayne plots of Central Otago. Proceedings of the NZ Ecological Society 17: 18-24.

Douglas, J.A. 1974. A review of the grass species introductionsinto the tussock grasslands of the South

Island, New Zealand. Proceedings of the NZ Grassland Association 36: 224-239.

Eamshaw, G.F. 1910. Grass and clover variety trials: Moumahaki NZ journal of agriculture I: 205-210.

Gibson, D.J. 1988. The relationship of sheep grazing and soil heterogeneity to plant spatial patterns in dune grassland. Journal of Ecology 76/1: 233-252.

Hafenrichter, A.L. et al. 1968. Grasses and legumes for soil conservation in the Pacific NW and Great Basin States. USDA Agriculture Handbook, No, 339: 5-6.

Hilgendorf, F.W. 1940. Pasture plants and pastures of New Zealand. Whitcombe \& Tombes Ltd., 5th Ed., 94 pp.

Levy, E.B. 1925. The grasslands of New Zealand. $N Z$ journal of agriculture 30 : 357-374.

Lunn, W.A. 1951. Regrassing experiments on depleted country in Central Otago. NZ journal of agriculture 83: 363-368.

MacKay, T. 1887. A manual of the grasses and forageplants useful to New Zealand. Govt. Printer, Wellington.

MacPherson, A. 1910. Report on grassing denuded country, Mackenzie Plains and Central Otago. NZ journal of agriculture 1: 477-479.

MacPherson, A. 1912. Revegetating experiments on depleted country. NZ journal of agriculture 4: 2122, 308-3 11.

MacPherson, A. 1913. Regrassing depleted areas, Journal of Department of Agriculture 6: 596-597.

Mahmoud, A.; Grime, J.P.; Furness, S.B. 1975. Polymorphism in Arrhenatherum efatius (L.) Beauv. ex J. \& C. Presl. New phytologist 75: 269-276.

Moore, L.B. 1976. The changing vegetation of Molesworth Station, New Zealand, 1944-1971. NZ DSIR, Bulletin 217, Govt. Printer, Wellington: 118 pp.

Pfitzenmeyer, C.D.C. 1962. Biological flora of the British Isles " Arrhenatherum elatius (L.). Journal of ecology 50: 235-245.

Plummer, A.P.; Christensen, D.R.; Monsen, S.B. 1968. Restoring big-game range in Utah. Utah Div, of Fish \& Game, Pub. No. 68-3. 183 pp.

Rorison, I.H.; Peterkin, J.H.; Clarkson, D.T. 1983. Nitrogen source, temperature and the growth of herbaceous plants. In: Eds. Lee, J.A. et al. Nitrogen as an ecological factor. Blackwell Scientific. 189201

Scott, D. et al. 1985. Limitations to pasture production and choice of species. In: Eds. Burgess, R.E. and Brock, J.L. Using herbage cultivars. NZ Grassland Association, Grassland research \& practice series \#3.

Vassileva, T. 1987. Soil-conserving and water-regulating ability of some perennial grasses grown on slightly to moderately eroded lands. Pochvoznanie,Agrokhimiya-i-Rastitelna-Zashchita 22:3: $\quad$ 60-65.

Voight, P.W.; MacLauchlan, R.S. 1985. Native and other western grasses. pp. 177-187. In: Eds. Heath, M.E., Barnes, R.F. and Metcalfe, D.S. Forages. The science of grassland agriculture. Iowa State Univ. Press.

Whyte, R.O.; Moir, T.R.G.; Cooper, J.P. 1975. Grasses in Agriculture. FAO Agricultural Studies, No 42: 312.

Wheeler, W.A. 1950. Special crops • grasses (Tall Oatgrass). In: Forage and pasture crops. D. Van Nostrand \& Co, $752 \mathrm{pp}$.

Wills, B.J.; Begg, J. S. 1986. The Cockayne plots of Central Otago - a 1985 evaluation. NZ journal of ecology 9: $4 \quad 1-55$.

Woodman, R.F.; Fraser, W.J. 1991. Alternative grass options for dry east coast and downland pastoral sytems. Proceedings of the Agronomy Society of $\mathrm{Nz}$ 21: 45-53. 